\title{
INFLUENCE OF DIFFERENT PERCENTAGE BOILER ASH-BASED GEOPOLYMER IN LATERITE SOIL
}

\author{
ATIQAH NaJWA Zainuddin ${ }^{*}$, MAZIDAH MUKRI ${ }^{2}$, Diana Che Lat ${ }^{1}$, \\ Roslizayati Rosli ${ }^{1}$ AND NoOR HidaYu ABdul RANI ${ }^{3}$ \\ ${ }^{I}$ Faculty of Civil Engineering, \\ Universiti Teknologi MARA (UiTM) Johor Branch, \\ Kampus Pasir Gudang, Johor, Malaysia \\ ${ }^{2}$ Faculty of Civil Engineering, \\ Universiti Teknologi MARA (UiTM) Selangor, Malaysia \\ ${ }^{3}$ Faculty of Chemical Engineering, \\ Universiti Teknologi MARA (UiTM) Johor Branch, \\ Kampus Pasir Gudang, Johor, Malaysia \\ *Corresponding author: atiqa387@uitm.edu.my
}

(Received: 23rd August 2020; Accepted: $9^{\text {th }}$ January 2021; Published on-line: $4^{\text {th }}$ July 2021)

\begin{abstract}
The waste generation of palm oil boiler ash has been one of its big problems as it is less used and deposited in landfills as a by-product. Geopolymer is a new green technology that has been intensively studied in concrete applications. However, few studies on geopolymers have been conducted in soil applications. Thus, this study investigated the influence of palm oil boiler ash-based geopolymer in laterite soil strength. Different percentages, 5, 10, 15, and 20\% of geopolymer mixtures, were added to laterite soil. The process of producing a geopolymer binder was performed by sieving boiler ash $(150 \mu \mathrm{m})$, then mixing with sodium hydroxide $(\mathrm{NaOH})$ and sodium silicate $\left(\mathrm{Na}_{2} \mathrm{SiO}_{3}\right)$ as an alkaline activator at a ratio of 1:2. This material effectiveness was tested through compaction test using a standard proctor, unconfined compressive strength, and the scanning electron microscope (SEM). Fifteen percent (15\%) of geopolymer in laterite soil indicated the best-mixed design with a maximum dry density of $2.23 \mathrm{Mg} / \mathrm{m}^{3}$ with a moisture content of $13.58 \%$. The unconfined compressive strength test at curing times of zero, seven, and twenty-eight days on the LS-15.0 GPOBA sample, show a slightly increased strength of 47,58 , and $76 \mathrm{kPa}$, respectively. The SEM images proved that the geopolymer gel's development stabilized the soil structure from a loose structure to a denser soil structure. This study aims to investigate the influence of geopolymer in laterite soil. Boiler ash as an alternative material in geotechnical applications was studied to understand and develop new green alternative materials to sustain the environment from industrial waste and to enhance laterite soil properties.
\end{abstract}

ABSTRAK: Abu kelapa sawit adalah salah satu sisa utama yang terhasil dari industri kelapa sawit tetapi penggunaannya kurang dimanfaatkan dan dibuang ke tempat pembuangan sampah. Teknologi hijau baru yang dikenali sebagai geopolimer telah dikaji secara intensif dengan kekuatan konkrit tetapi hanya sedikit kajian telah dibuat dalam penggunaan tanah. Tujuan kajian ini adalah bagi mengesan geopolimer berasaskan abu kelapa sawit terhadap kekuatan tanah laterit. Peratusan campuran geopolimer yang berbeza $(0,5,10,15$ dan 20\%) dicampur pada tanah laterit. Bagi menghasilkan geopolimer, saiz $150 \mu \mathrm{m}$ abu kelapa sawit disintesis dengan kombinasi bahan kimia natrium hidroksida $(\mathrm{NaOH})$ dan natrium silikat $\left(\mathrm{Na}_{2} \mathrm{SiO}_{3}\right)$ pada nisbah 1:2 bagi semua campuran sebagai pengaktif alkali. Ujian terhadap keberkesanan bahan adalah melalui proses ujian pemampatan menggunakan proktor standard, kekuatan pemampatan tidak terbatas, dan Pengimbas Mikroskop Elektron (SEM). Berdasarkan dapatan ujian 
pemadatan, $15 \%$ geopolimer di tanah laterit menunjukkan campuran terbaik dengan memberikan kepadatan pengeringan maksimum $2.23 \mathrm{Mg} / \mathrm{m}^{3}$ pada kelembapan $13.58 \%$. Ujian kekuatan mampatan tidak terbatas pada masa pempolimeran sebanyak 0, 7 dan 28 hari diuji pada sampel LS-15.0GPOBA bagi menguji kekuatan campuran. Dapatan menunjukkan kekuatan geopolimer sedikit meningkat pada 47, 58 dan 76, masing-masing. Imej SEM membuktikan pengembangan gel geopolimer menstabilkan struktur tanah daripada struktur lopong kepada struktur tanah padat. Oleh itu, abu kelapa sawit berasaskan geopolimer dan tanah laterit berpotensi sebagai alternatif bagi merawat tanah dalam aplikasi geoteknik dan berpotensi mengurangkan kadar kebolehtelapan.

KEYWORDS: palm oil boiler ash; geopolymer; laterite soil; compaction compressive strength

\section{INTRODUCTION}

Increased population is leading to higher demand in the construction industry and the growth of infrastructure. Malaysia is the largest exporter of palm oil mill. The production of palm oil in Malaysia has had a positive impact on sustained economic growth in the global market over the past four decades, and the annual production of palm oil in Malaysia in the period of 2016-2020 has reached 15.4 million tons [1]. Despite the apparent benefits, oil palm mills' production significantly contributes to environmental degradation [2].

Production from palm oil processing for oil extraction generates waste such as palm kernel, nutshell, palm fiber, and empty fruit brunch. These wastes are incinerated and produce ashes at the boiler's lower compartment, known as boiler ash. It has now been revealed that the palm oil industry will produce 657,000 tons of waste at the end of December 2020 [3]. The wastes are either dumped to landfill or eventually exposed and contaminate the soil, creating a significant disposal issue and harming the environment [4].

Nowadays, Ordinary Portland Cement (OPC) and lime have become the most common soil stabilizers used as additives to enhance soil properties. However, the use of Ordinary Portland Cement (OPC) is held responsible for some $\mathrm{CO}_{2}$ emission during its production and has thus polluted the environment. Several efforts are in progress to reduce Ordinary Portland cement as an additive material in soil stabilization to address global warming issues. Studies are being conducted to find alternative and eco-friendly soil stabilizers from waste material to reduce $\mathrm{CO}_{2}$ emission and decrease construction costs. Therefore, in this study, boiler ash was introduced as an alternative by-product material in soil stabilizer by synthesizing it into geopolymer form.

Daviddovits [5] introduced a new green technology known as geopolymer to enhance mechanical properties and material strength in the construction industry. All the materials that contain $\mathrm{Si}$ and $\mathrm{Al}$ can be used as a constituent in geopolymer to be activated with alkali solution presence [6]. According to Van Jaarsveld et al. [7], the $\mathrm{SiO}_{2}$ and $\mathrm{Al}_{2} \mathrm{O}_{3}$ in the ash provide a rich source of $\mathrm{Si}$ and $\mathrm{Al}$ atoms as a source of aluminosilicate materials for producing geopolymers. Xu et al. [8] investigated 16 natural Al-Si minerals and concluded that all the minerals are, to some extent, soluble in concentrated alkaline solution.

According to Daviddovits, geopolymerization is a reaction that consists of $\mathrm{Si}-\mathrm{O}-\mathrm{Al}$ and $\mathrm{Si}-\mathrm{O}-\mathrm{Si}$ bonds depending on the ability of alumina ion (6-fold or 4-fold coordination) to induce the crystallographer and chemical changes in silica backbone. In geopolymerization, a reaction three-dimensional techto-aluminosilicate framework called polysialate is shown in Equation (1), where $\mathrm{M}$ is a cation $(\mathrm{K}, \mathrm{Na}, \mathrm{Ca}), \mathrm{n}$ is the degree of polycondensation, and $\mathrm{z}$ is $1,2,3$ or $\geq 3$. In the sialates network, Si-O-Al bridge forms form the chain and ring of 
$\mathrm{SiO}_{4}$ and $\mathrm{AlO}_{4}$ tetrahedra's cross-linked together with oxygen atoms. Positive ions $\left(\mathrm{Na}^{+}, \mathrm{K}^{+}\right.$, $\mathrm{Ca}^{2+}$ ) must balance the negative charge if $\mathrm{Al}$ is in 4-fold coordination [7].

$$
\mathrm{Mn}\left[-\left(\mathrm{SiO}_{2}\right) \mathrm{z}-\mathrm{AlO}_{2}\right] n-\mathrm{wH}_{2} \mathrm{O}
$$

Previous researchers have investigated the application of geopolymer by using different waste materials, including sludge, fly ash, kaolin, risk husk, and slag [9-11]. The boiler ash contained the sum of $\mathrm{SiO}_{2}$ and $\mathrm{Al}_{2} \mathrm{O}_{3}$ about 44 to $55 \%$ which is the most required composition to produce geopolymer [12-13]. The researchers have systematically studied the effect of using different alkaline solutions, sodium hydroxide concentrations, curing times, temperatures, and sodium hydroxide and sodium silicate ratios [14-15]. Duchesne et al. [16] in their study, proved that $\mathrm{NaOH}$ presence in alkaline solution activated the reaction, dissolved $\mathrm{Si}^{4+}$ and $\mathrm{Al}^{3+}$, and produced smooth gel to fly ash. The presence of sodium silicate in the alkaline solution resulted in the rapid process of geopolymerization.

Khan et al. [17] agreed that the higher the percentage of fly ash-based geopolymer added, the higher the value of compressive strength. In one of his samples, $70 \%$ of compressive strength was achieved using fly ash geopolymer in cement compared to the use of ground granulated blast furnace slag (GGBS) in cement with only a $30 \%$ increase. The concentration of sodium hydroxide played an important role in dissolving the silica-alumina from the source material. In cement application, most of NaOH's molarity is 8 to $16 \mathrm{M}$ at curing days of seven to twenty-eight days. As agreed by Emdadi et al. [18] in their study, compressive strength was intensively ranging from 10-14 M NaOH. Different molarity of $\mathrm{NaOH}$ gives a different effect on geopolymer. In Puertas et al. [19], a mixture of fly ash and $\mathrm{NaOH}$ of $10 \mathrm{M}$ was added to slag, resulting in compressive strength of approximately 50 $\mathrm{MPa}$. Investigation on the potential use of geopolymer of low calcium fly ash with different ratios of alkali activator, M1(0.5), M2(1.0), M3(1.5), M4(2.0), and M5(2.5), at curing time of three days gave compressive strength of 34.7, 61.6, 40.4, 40.5, and 22.3 MPa respectively. As agreed by Skvara et al. [20] who observed the increasing ratio from 2 to 2.5, the compressive strength decreased due to the excess sodium silicate hindering water evaporation and structure formation.

Soil stabilization is a typical soil remediation method to improve the physical and chemical properties of low strength soil by mixing the potential raw materials as additives or processes. Laterite soil is known to be very resistant to erosion. Laterite soil can be demonstrated by the nature of its properties such as high shear strength, low infiltration capacity, and low clay content, making it an excellent geotechnical material [21]. Ahmad Sujeeth et al. [22] mentioned that laterite soil properties can easily change as it is exposed to air and water during construction. Laterite soil is full of cavities and pores; therefore, it is crucial to select sufficient treatment in laterite soil to enhance soil strength and properties. Marto et al. [23] stated that laterite is widely used and economically convenient in construction. Hence, information on laterite properties is essential to design the geotechnical process's strength and durability in construction.

In recent years, the stabilization technique has been studied using geopolymerization. The geopolymer has become an effective method because the geopolymer source is cheaper since it uses industrial waste and reduces environmental pollution. Varied types of soil such as red mud soil, laterite soil, loess deposit, and sandblasting grit have been studied using a geopolymer to improve the soil properties [24-27].

Thiha et al. [28] studied the shear parameter of three soil types at curing times of zero and seven days. $\mathrm{NaOH}$ and $\mathrm{Na}_{2} \mathrm{SiO}_{3}$ were used as alkaline solutions and mixed with fly ash to produce a geopolymer. The ratio of fly ash-geopolymer to the soil was at 0.1 . In the study, 
soil with silty sand and high plasticity clay gave a higher soil strength than high plasticity silt at a curing time of seven days. Moreover, geopolymer curing at seven days was higher at $30 \%$ at day zero. This was supported by Wisam et al. [29] who made an extension of research to investigate $\mathrm{NaOH}$ 's different molarity $(4,6,8,10$ and $12 \mathrm{M})$ in geopolymer technique. Control soil samples displayed a UCS value of $77.9 \mathrm{kPa}$. Alkali activation for soil-olivine mixture increased the strength of the mixture to 392.8, 421.4, 583.91082 .8 and $904.3 \mathrm{kPa}$ at 7 days, respectively. As a conclusion on this research, geopolymer reaction gives higher soil strength over time. Alkaline activator dissolves the bonding of $\mathrm{Si}-\mathrm{Al}-\mathrm{Si}$ from the source material and gains stronger atom bonding. Further study on the long-term performance should be carried out on boiler ash to compare other raw materials' effectiveness.

Nik et al. [30] studied the effectiveness of different percentages of class C fly ash geopolymer on the compaction effort used in a soil liner application. In their study, an investigation of compaction and a hydraulic conductivity test were conducted. Based on the compaction test, $15 \%$ of the geopolymer gave optimum MDD, which led to a good hydraulic conductivity test. MDD $20 \%$ of the geopolymer decreased as the excess water in the geopolymer failed the geopolymerization.

A few works have studied the use of geopolymer binder as material in soil improvement such as sludge, fly ash, kaolin, risk husk, and slag [9-11]. However, no Malaysian works have used boiler ash as geopolymer source material. It is essential to carry out a study to understand and develop new green alternative materials to sustain the environment from industrial waste and convert it into alternative raw materials to enhance soil properties. This study investigates the potential of boiler ash as source material in producing a geopolymer to enhance laterite soil properties and sustain the environment.

\section{METHODOLOGY}

Laboratory work was carried out in the Faculty of Civil Engineering in UiTM Johor Kampus Pasir Gudang, Johor, Malaysia. The total number of samples in this study was nine samples for chemical properties, sixteen samples for physical properties, five samples for compaction value, and three samples for unconfined compression test conductivity with a total of thirty-three samples. The sample number and sample definition of this analysis are shown in Table 1. The best percentage of boiler-ash geopolymer added to laterite soil was investigated using five different percentages, $(0,5,10,15$, and $20 \%)$. This percentage was determined based on the previous soil stabilization literature review [31-32].

Table 1: Soil descriptions

\begin{tabular}{ccl}
\hline No & Sample Number & \multicolumn{1}{c}{ Soil Description } \\
\hline $\mathbf{1}$ & LS - P & Laterite Soil + 0\% POBA geopolymer \\
$\mathbf{2}$ & LS -5.0 GPOBA & Laterite Soil + 5.0\% POBA geopolymer \\
$\mathbf{3}$ & LS -10.0 GPOBA & Laterite Soil $+10.0 \%$ POBA geopolymer \\
$\mathbf{4}$ & LS -15.0 GPOBA & Laterite Soil $+15.0 \%$ POBA geopolymer \\
$\mathbf{5}$ & LS -20.0 GPOBA & Laterite Soil $+20.0 \%$ POBA geopolymer \\
\hline
\end{tabular}

Three stages of laboratory work were conducted to determine the physical properties. The Atterberg test, $\mathrm{pH}$ test, particle density test, and shrinkage test followed the British Standard BS 1377-2:1990. Scanning electron machine (SEM) was utilized at the Faculty of Chemical Engineering, UiTM Johor Kampus Pasir Gudang, and X-Ray Fluorescence at Jabatan Kimia UTM Skudai Johor, covering the chemical properties test to determine the 
soil structure of laterite soil mixed with geopolymer and the chemical composition in palm oil boiler ash. Compaction and unconfined compression strength (UCT) engineering tests were performed to investigate the reaction of soil strength to geopolymer. Fig. 1 shows the study flow chart in this study.

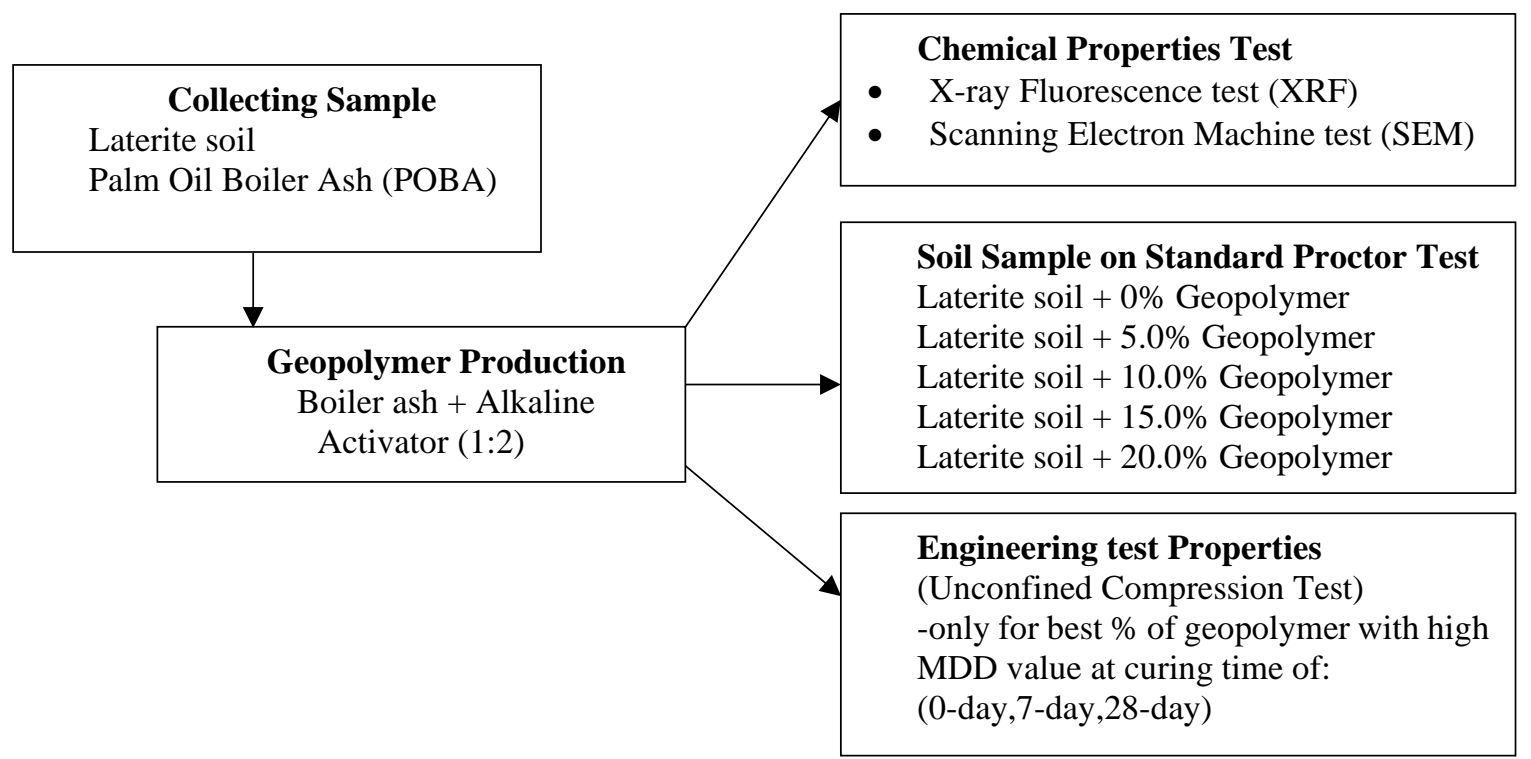

Fig 1: Study flow chart.

\subsection{Materials}

In this study, laterite soil was mixed with a geopolymer to produce a good binder to enhance the properties of laterite soil. To generate a geopolymerization reaction, raw material from industrial waste known as palm oil boiler ash and alkaline activator (sodium hydroxide and sodium silicate) were mixed with a suitable mixed design as discussed below, thus generating a new green technology binder known as geopolymer. Data of properties and soil strength at different percentages of boiler ash- geopolymer mixed in laterite soil were recorded.

\subsubsection{Laterite Soil}

The laterite soil used was collected at a depth of $1.5 \mathrm{~m}, 100 \mathrm{~m}$ away from Tanjung Langsat Landfill, Pasir Gudang, Johor, Malaysia. The gradation test was conducted using BS 1377: Part 2:1990. Fig. 2 shows the gradation chart of the laterite soil. From the sieve analysis test, the laterite soil used in this study consisted of about $25.98 \%$ of gravel, $35.55 \%$ of sand, and $38.47 \%$ of fine size grain and was classified under very "silty sand" as shown in Table 2. The laterite soil had a specific gravity of 2.62. An Atterberg limit test that was conducted on the laterite soil of sieve size $425 \mu \mathrm{m}$ showed the result of the liquid limit (LL) of the soil was $58.61 \%$ and the plastic index (PI) was 6.15\%. According to the Unified Soil Classification system (USCS), this soil is classified as high plasticity (MH). The laterite soil in this study consisted of a high portion of silt compared to clay resulting in a low shear strength or low compressibility. This type of soil was therefore chosen in this study to investigate the effect of geopolymer palm oil (boiler ash) to enhance the mechanical and properties of laterite soil. 


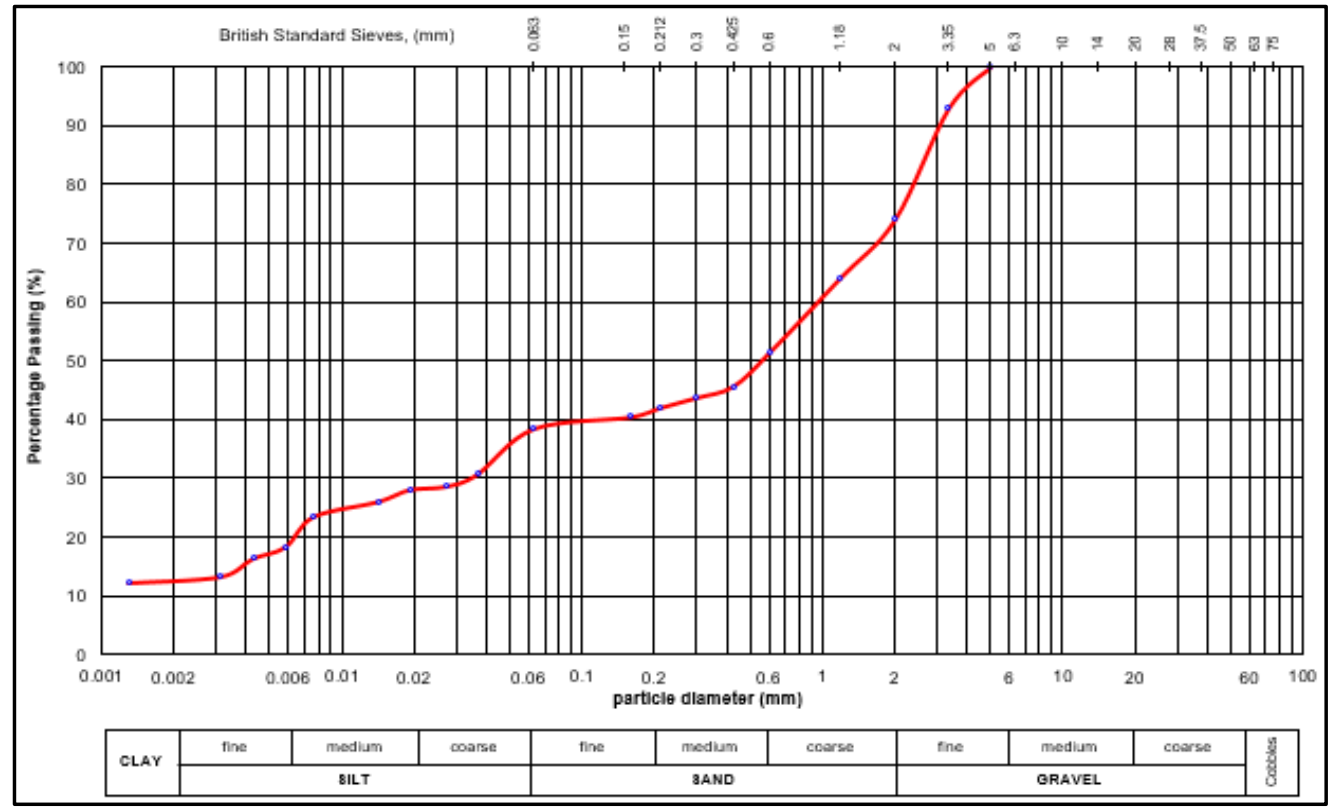

Fig. 2: Grain size distribution of laterite soil.

Table 2: Grading characteristics of the laterite soil

\begin{tabular}{lcc}
\hline \multicolumn{3}{c}{ Composition of soil } \\
\hline Gravel \% & 25.98 \\
Sand \% & 35.55 \\
Silt \% & 25.81 \\
Clay $(\%)$ & 12.66 \\
\hline \multicolumn{3}{c}{} \\
\hline $\mathrm{D}_{60}(\mathrm{~mm})$ & Gradation \\
$\mathrm{D}_{50}(\mathrm{~mm})$ & & 0.995 \\
$\mathrm{D}_{30}(\mathrm{~mm})$ & & 0.558 \\
\end{tabular}

\subsubsection{Palm Oil Boiler Ash (POBA)}

Palm oil boiler ash (POBA) was sourced from Teluk Sengat palm oil mill, Kota Tinggi, Johor. The palm oil boiler ash, as shown in Fig.3, consisted of boiler ash that was obtained from the lower compartment of a palm oil boiler burning what consisted of large particles including nutshells and kernels. Palm oil boiler ash is one of the industrial wastes from the burning of palm oil that creates disposal problems and causes soil contaminants as the waste is stored in landfills. The chemical composition of the palm oil boiler ash was determined using x-ray fluorescence (XRF), as shown in Table 3. The higher content of silica could be the potential of a geopolymer.

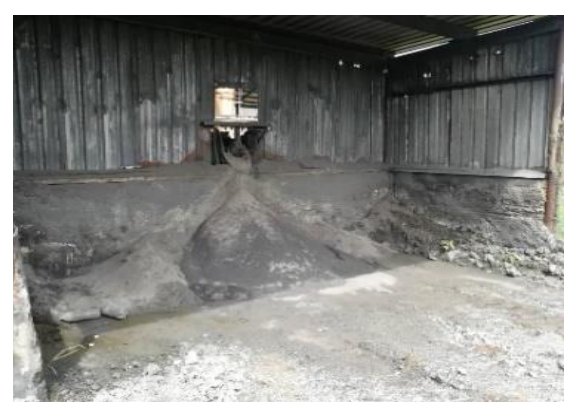

Fig. 3: Palm oil boiler ash (POBA) in Teluk Sengat Palm Mill, Johor. 
Table 3: Chemical composition of laterite soil and boiler ash

\begin{tabular}{lcccccccc}
\hline Oxides & $\mathrm{SiO}_{2}$ & $\mathrm{Al}_{2} \mathrm{O}_{3}$ & $\mathbf{C a O}$ & $\mathrm{Fe}_{2} \mathrm{O}_{3}$ & $\mathrm{Na}_{2} \mathrm{O}$ & $\mathrm{MgO}$ & $\mathrm{P}_{2} \mathrm{O}_{5}$ & $\mathbf{K}_{2} \mathbf{O}$ \\
\hline Laterite Soil (LS-P) & 56.0 & 30.3 & 0.381 & 9.54 & - & - & - & 0.290 \\
Palm Oil Boiler Ash (POBA) & 43.9 & 4.55 & 13.1 & 4.11 & - & 3.27 & 2.45 & 12.5 \\
\hline
\end{tabular}

Based on Table 3, the percentage of boiler ash was suitable to be a geopolymer source material as the percentage of silica was more than $40 \%$ [5]. In laterite soil, the silica-alumina comprised 30 percent to 60 percent content. However, the properties of laterite soil were complex such as shrinkage and low plastic index due to the presence of water. Therefore, it was not sufficient for laterite soil alone without additives to be the source material for geopolymerization production. Fig. 4 shows the size sample of the palm oil boiler ash at $150 \mu \mathrm{m}$ used in this study.

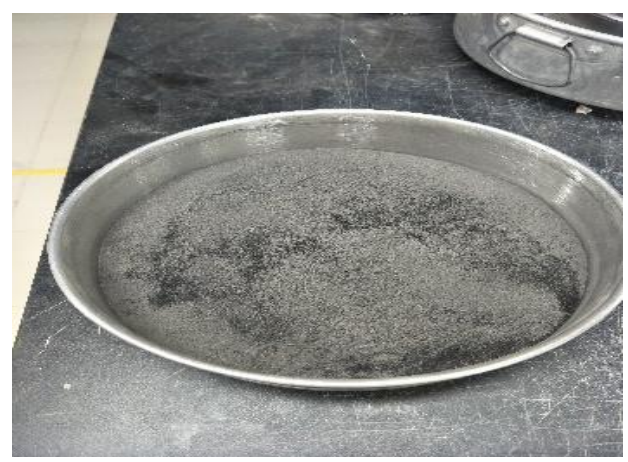

Fig. 4: Palm oil boiler ash passing $150 \mu \mathrm{m}$ sieve size.

\subsubsection{Alkaline Solution}

The alkaline activator used in this study was sodium hydroxide $(\mathrm{NaOH})$ in pellet form with $97 \%$ purity and sodium silicate $\left(\mathrm{Na}_{2} \mathrm{SiO}_{3}\right)$, as shown in Fig. 5 . Referring to Thiha et al. [28], the concentration of sodium hydroxide $(\mathrm{NaOH})$ in this study was chosen to be $5 \mathrm{M}$. Sodium silicate $\left(\mathrm{Na}_{2} \mathrm{SiO}_{3}\right)$ was a liquid solution that consisted of $9.4 \% \mathrm{Na}_{2} \mathrm{O}, 30 \% \mathrm{SiO}_{2}$, and $60.5 \% \mathrm{H}_{2} \mathrm{O}$ taken from chemical suppliers in Johor. The ratio of sodium hydroxide $(\mathrm{NaOH})$ and sodium silicate $\left(\mathrm{Na}_{2} \mathrm{SiO}_{3}\right)$ in the study was 1:2.

\subsection{Sample Preparation}

The palm oil boiler ash was collected and ground to finer particles and sieved using 150 $\mu \mathrm{m}$ sieves and put in an oven at $80^{\circ} \mathrm{C}$ for 24 hours to activate the silica content before being mixed with an alkaline activator. The fine particles of palm oil boiler ash were used to produce the geopolymerization reaction between palm oil boiler ash and alkaline solution at different mixed designs. The purpose of using an alkaline activator was to synthesize the chemical structure of palm oil boiler ash to produce a geopolymer. Sodium hydroxide $(\mathrm{NaOH})$ and sodium silicate $\left(\mathrm{Na}_{2} \mathrm{SiO}_{3}\right)$ were selected at a ratio of 1:2. The sodium hydroxide $(\mathrm{NaOH})$ pellets were prepared by diluting them with distilled water at a concentration of 5 $\mathrm{M}$ (molarity) to create an alkaline solution. The concentration of the sodium hydroxide solution $(\mathrm{NaOH})$ used was $5 \mathrm{M}$. For preparation of $1 \mathrm{M}$ solution, $40 \mathrm{~g} \mathrm{NaOH}$ flakes were dissolved in water to prepare 1 liter of sodium hydroxide solution. Thus, for preparation of $5 \mathrm{M}, 200 \mathrm{~g}$ of $\mathrm{NaOH}$ flakes were used. 

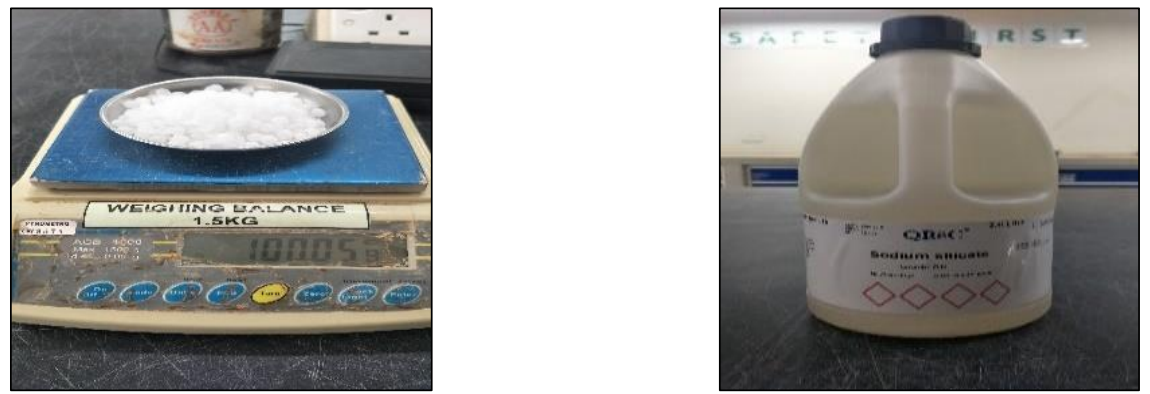

Fig. 5: (left) Sodium hydroxide in pellet form; (right) Sodium silicate in liquid form.

During the preparation of $\mathrm{NaOH}$, precautions were taken to put the pellets into the distilled water and not the other way around as sodium hydroxide could react with moisture from the air and generate heat while dissolving and cause a fire near flammable material, as well as possible sparks that could come into contact with eyes or skin. The sodium silicate was poured into the $\mathrm{NaOH}$ solution at a ratio of 1:2, stirred for 10 minutes, and left at room temperature for 24 hours to produce a better strength of mortar [12]. Lastly, to produce the geopolymer binder, $80 \%$ of boiler ash and $20 \%$ of alkaline solution were carefully mixed before being added to laterite soil at a different percentage of mixed design, as shown in Fig. 6.

After the geopolymer curing at ambient temperature for 24 hours, the geopolymer was mixed with laterite soil at a different percentage of $0,5,10,15$, and $20 \%$ as shown in Fig. 7 The samples were then tested to determine the physical properties, chemical properties, compaction test, and soil strength using an unconfined compression test (UCT) at zero, seven, and twenty-eight days of curing.

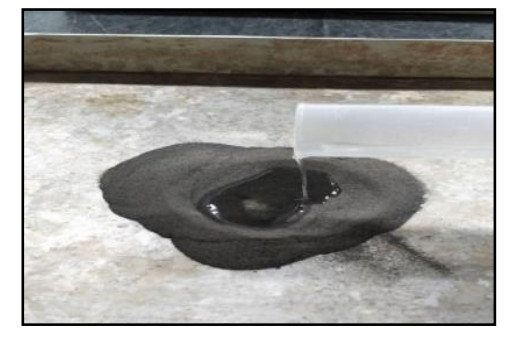

Fig 6: Alkaline solution mixed with POBA.

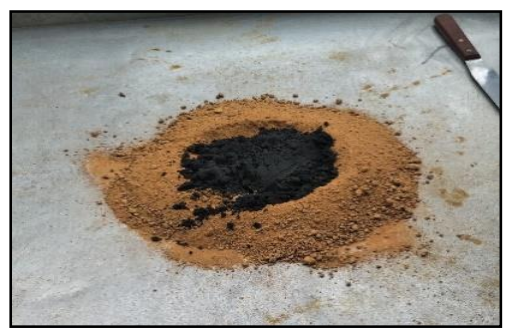

Fig 7: Preparation of geopolymer mixed with laterite soil.

\subsection{Experimental Design}

\subsubsection{Compaction Test}

Five samples at different percentages of geopolymer $(0,5,10,15$, and 20\%) were prepared. The percentage of water required was added and mixed until a uniform consistency was achieved [30]. The standard proctor test as shown Fig.9 was conducted in this study to determine the maximum dry density (MDD) and optimum moisture content (OMC). The soil sample was dynamically compacted with a release of a steel hammer with a weight of $2.5 \mathrm{~kg}$ and 27 blows per each of three layers, falling freely $300 \mathrm{~m}$ with a $50 \mathrm{~mm}$ diameter of rammer. After compaction was conducted, samples were then trimmed to remove the excess soil, molded, and weighed. Equation (2) and Equation (3) show the calculation of the standard proctor test: 
$\rho=\frac{m_{2}-m_{1}}{v} \mathrm{Mg} / \mathrm{m}^{3}$

where:

$\mathrm{m}_{1}=$ mass of mold and base

$\mathrm{m}_{2}=$ mass of soil and mold

$\mathrm{V}=$ volume of mold

Then, dry density was calculated from the equation below:

$\rho=\left(\frac{100}{100+w}\right) \rho \quad M g / m^{3}$

The dry density was recorded to determine the optimum moisture content (OMC) at the maximum dry density (MDD) to conduct an unconfined compression test (UCT).

\subsubsection{Unconfined Compression Test (UCT)}

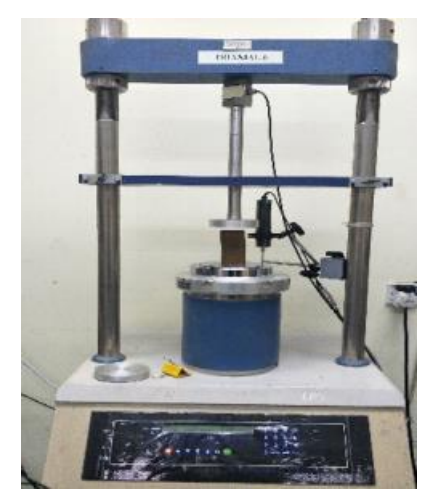

Fig. 8: UCT machine.

Unconfined compressive strength is based on ASTM Designation D2166. The size of samples in this test was $50 \mathrm{~mm}$ in diameter with $100 \mathrm{~mm}$ height based on the procedure in ASTM D2166. In this study, the investigation of unconfined strength was conducted for sample LS-15.0 GPOBA measured at curing times of the compacted sample under ambient temperature. Curing times of zero, seven, and twenty-eight days were chosen for this study. These samples were selected to determine the before and after reaction of the geopolymer towards laterite soil. Also, LS-15.0 GPOBA was chosen due to the best compaction obtained from MDD and OMC results.

The sample was mixed with water, based on moisture content resulting from the compaction test for LS- 15.0 GPOBA. Then, the samples were compacted in the mold with three (3) layers 10 tamping's of compaction for each layer. The compressed samples at zero day were immediately diverted and installed for the UCT test as shown in Fig. 8. Samples of seven and twenty-eight days were kept in a plastic bag and tightly sealed under ambient temperature based on curing times. When the sample reached its curing time, it was taken out and immediately run on the UCT machine. In this test, all samples were sheared with the dry condition without submerging the sample into water. 


\section{RESULTS AND DISCUSSION}

\subsection{Physical Properties of Samples}

This study conducted laboratory investigations on different percentages of geopolymers to enhance the properties of laterite soil. This study aimed to determine the soil compaction and shear strength of geopolymer as additives in laterite soil. Table 4 shows the physical properties of laterite soil. The properties and characteristics of laterite soil are important to be investigated for the future development of laterite soil.

Table 4: Physical properties of different percentages of geopolymer in laterite soil

\begin{tabular}{ll}
\hline Soil Description & LS-P \\
\hline Liquid Limit (\%) & 58.61 \\
Plastic Index (\%) & 6.15 \\
Specific Gravity & 2.62 \\
Ph & 6.49 \\
Shrinkage & 11.49 \\
\hline
\end{tabular}

Based on the experimental data collected, with the right percentage of boiler ash-based geopolymer added to laterite soil, it improves the properties of soil and enhances the soil strength. Further investigation in the compaction test and soil strength was conducted as follows.

\subsection{Compaction Test}

Fig. 10 shows the compaction curve indicating maximum dry density (MDD) and optimum moisture content (OMC) of all geopolymer percentages in laterite soil. Based on the compaction curve produced, $0 \%$ of geopolymer in laterite soil gave a maximum dry density of $1.80 \mathrm{Mg} / \mathrm{m}^{3}$ at $14.07 \%$ optimum moisture content. The adding of geopolymer at $5 \%$ and $10 \%$ showed increasing maximum dry densities of $1.88 \mathrm{Mg} / \mathrm{m}^{3}$ and $1.90 \mathrm{Mg} / \mathrm{m}^{3}$ and decreasing optimum moisture contents at $13.88 \%$ and $13.70 \%$, respectively. The increase of moisture content was probably because of the reaction between laterite soil, and geopolymer led to the loss of water [27]. However, drastic increase can be seen of maximum dry density of $2.23 \mathrm{Mg} / \mathrm{m}^{3}$ and decrease of optimum moisture content at $13.58 \%$ at $15.0 \%$ of geopolymer in laterite which give positive results of geopolymerization reactions. 15.0 $\%$ of geopolymer in laterite soil indicated the optimum mixed design of geopolymer as a mixed design. The bonding created by alkaline solution and the subsequent isomorphous substitution of silica $(S I)$ has indeed increased the packing between the grains [32]. This result is supported by Nik et al. [30] in their study on laterite soil and fly ash geopolymer mentioned, whereby geopolymer added in laterites soil showed an increment in dry density due to the action of alkaline attack which changed the soil mineral. In $20 \%$ of geopolymer, results gave a decreasing value of dry density of $1.71 \mathrm{Mg} / \mathrm{m}^{3}$ and increasing optimum moisture content at $16.38 \%$. This result happened due to the optimum and peak reaction achieved in $15.0 \%$ of geopolymer in laterite soil. The structure of silica-alumina in geopolymerization was lost due to increased moisture content because of the rapid reaction between geopolymer and laterite soil, which led to the loss of water. This result is in good agreement with the Noushini et al. [35] study of the behavior in laterite soil with sodium silicate-liquid stabilizer. Based on the result obtained from this study in compaction parameters, the increased percentage of geopolymer added to laterite soil gives increasing MDD and decreasing OMC. It was observed that the presence of a geopolymer in laterite 
soil gave a strong relationship between moisture content and maximum dry density shows the compaction curve of tested samples.

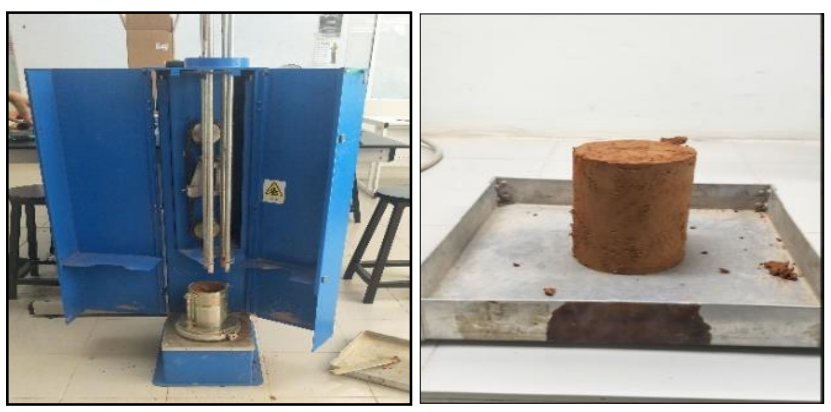

Fig. 9: Standard Proctor Machine and compaction sample.

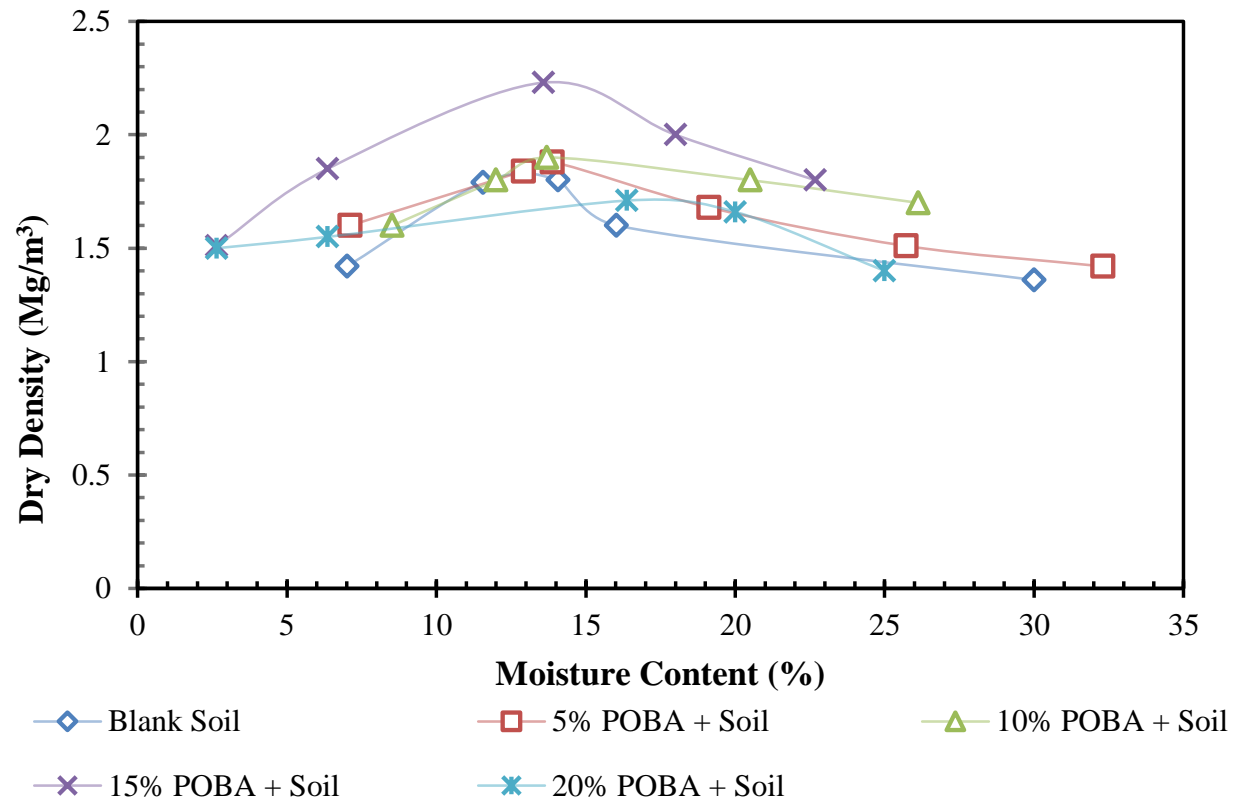

Fig. 10: Compaction Curve of Laterite soil with different percentages of geopolymer.

\subsection{Unconfined Compression Test (UCT)}

Soil compaction has direct effects on soil physical properties such as bulk density, strength, and porosity [36]. Therefore, the LS-15.0 GPOBA sample that gave the best value of maximum dry density (MDD) of $2.23 \mathrm{Mg} / \mathrm{m}^{3}$ was directly chosen as the optimum percentage to determine the soil strength using an unconfined compression test (UCT). In this study, the effect of compressive force on sample LS-15.0 GPOBA was investigated at different curing times of zero, seven, and twenty-eight days. The samples were compacted under moisture content based on the compaction parameter of LS- 15.0 GPOBA, which was $13.70 \%$. The pieces were cured at ambient temperature $\left(27^{\circ} \mathrm{C}\right.$ to $\left.30^{\circ} \mathrm{C}\right)$ reflecting the field conditions. The soil sample took on a hardened state after compacting. During the curing time, chemical reactions were expected to happen between the soil grain and the geopolymer molecules. Table 5 shows the samples from lowest strength at zero day of curing (47 kPa) after seven days of curing $(58 \mathrm{kPa})$. 


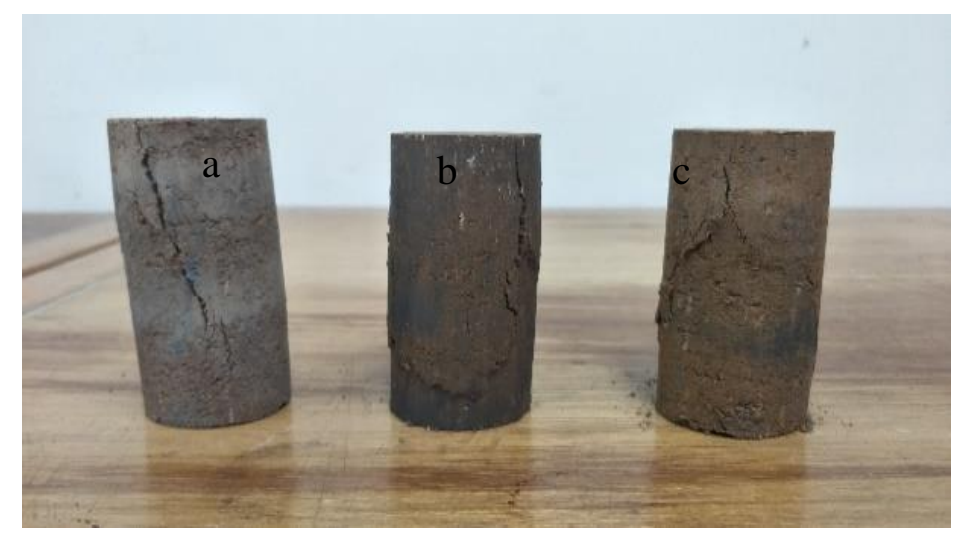

Fig. 11: (a) zero days, (b) seven days, (c) twenty-eight days of UCT.

The soil sample obtained after twenty-eight days achieved the highest compressive strength of $76 \mathrm{kPa}$. Fig. 12 showed a slight increase in compressive strength in increasing curing times of zero to twenty-eight days. The result is similar to previous studies [30,3738], where it shows the increment of compressive strength that proves the improvement of the geopolymerization process along the curing time. According to Emdadi et al. [18] the form of aluminosilicate and alkaline influences the effect of compressive force in geopolymer. Based on the result in this study, palm oil boiler ash (POBA) that contains a high percentage of silica can be used as pozzolanic materials to enhance the shear strength of soils. The geotechnical technology using a geopolymer can be a potential study and practice in applying soil strength such as soil slope, embankment, and landfill soil liner.

Table 5: Shear parameters of laterite soil with $15 \%$ of geopolymer at curing times of zero, seven, and twenty -nine days condition

\begin{tabular}{ccc}
\hline $\begin{array}{c}\text { Curing Time } \\
\text { (Days) }\end{array}$ & $\begin{array}{c}\text { Shear Strength } \\
(\mathbf{k P a})\end{array}$ & $\begin{array}{c}\text { UCS } \\
(\mathbf{k P a})\end{array}$ \\
\hline 0 & 47 & 94 \\
7 & 58 & 132 \\
28 & 76 & 153 \\
\hline
\end{tabular}

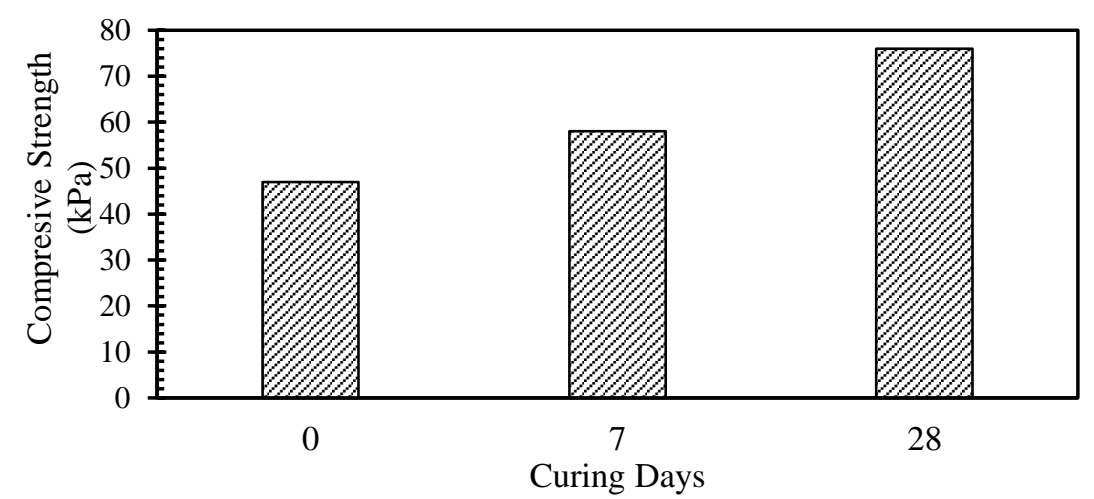

Fig. 12: The comparison of soil strength (LS-15.0 GPOBA) at zero, seven, and twenty-eight days of curing time. 


\subsection{Microstructure of Materials}

Fig 13 shows the morphological features of plain laterite soil (LS-P) and Fig 14 shows the laterite soil with $15 \%$ of geopolymer (LS.15.0 GPOBA) at a curing time of zero days. The test was examined using Scanning Electron Machine analysis using magnifying power 5000x at the Faculty of Chemical Engineering in UiTM Johor Campus, Pasir Gudang, Johor, Malaysia. As seen in Fig. 13, the structure layered with larger voids led to low compressive strength. The microstructure of the laterite soil without geopolymer can be found to be loose and not uniform; cracks and pores are observed between soil particles. Meanwhile, in Fig. 14 some particles show popcorn type and spherical type. Moreover, the structure of laterite soil with a geopolymer demonstrated a denser geopolymer matrix after the geopolymerization process with less pores compare to blank laterite. In the study by Temujun et al. [39] the soil structure becomes compact causing higher packing density, low porosity in microstructure, and leading to higher strength.

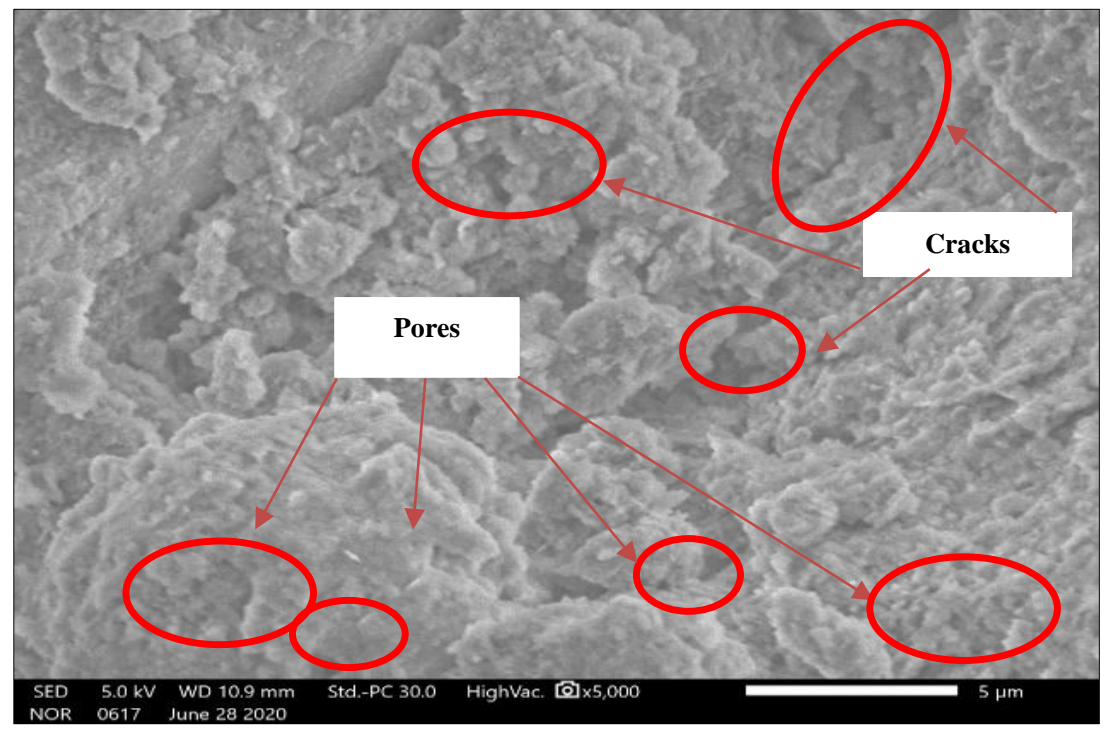

Fig. 13: SEM Samples of Plain Laterite (LS-P).

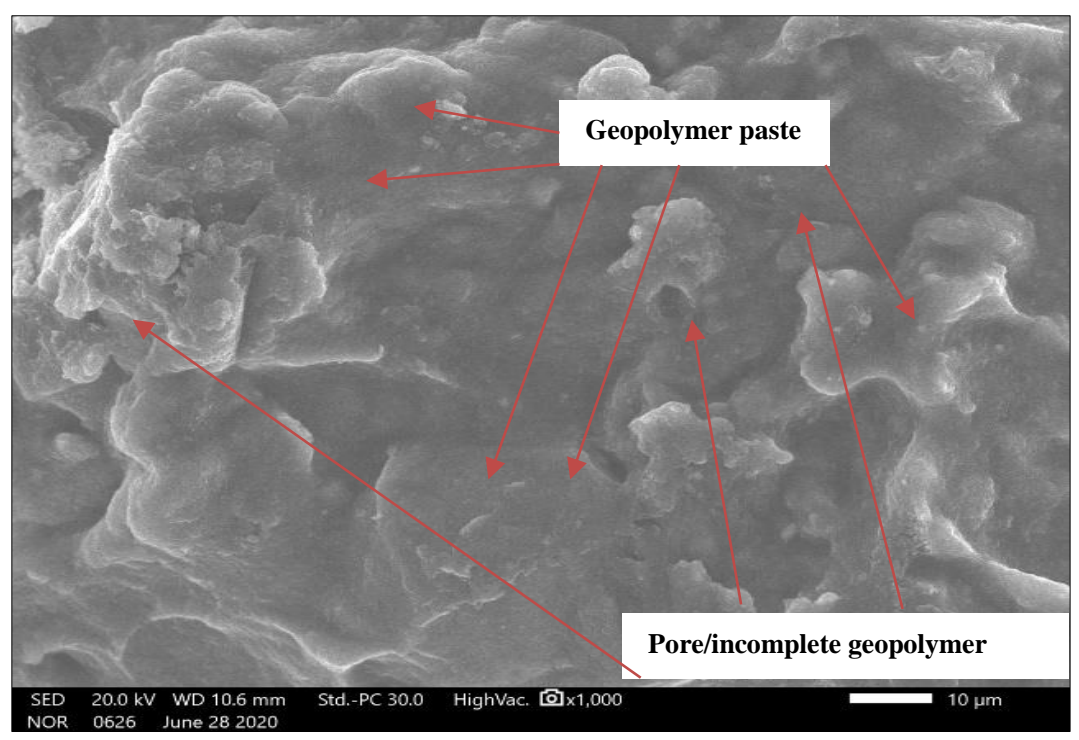

Fig. 14: SEM Samples of Laterite soil with $15 \%$ of Geopolymer (LS.15.0 GPOBA). 


\section{CONCLUSION}

This paper examines the influence of geopolymers on the properties of laterite soil to be applied in the field of geotechnical application. The palm oil boiler ash combined with an alkaline solution at a constant ratio to form a geopolymer binder has shown to have a beneficial effect on compaction and high compressive strength by improving the properties of the laterite soil. Based on the results of the study, the effective percentage of geopolymer in laterite soil was found at $15 \%$ that generated a maximum dry density of $2.23 \mathrm{Mg} / \mathrm{m}^{3}$ at $13.58 \%$ optimum moisture content which gave a good compaction parameter leading to the high strength of soil properties. The UCT was only conducted on the sample of LS.15.0 GPOBA, which offered the highest MDD. Samples were cured in a plastic bag at ambient temperature to suit field conditions at zero, seven, and twenty-eight days accordingly. Based on the experimental data, the compressive strength of the geopolymer slightly increased as curing days increased on zero, seven, and twenty-eight and gave the strength of 47, 58, and $76 \mathrm{kPa}$, respectively. Based on SEM test, it is apparent that it is due to the geopolymerization process that makes the sample harder and denser, which improves the soil strength. The SEM images have proven that the development of geopolymer gel in laterite soil has stabilized the soil structure from a loose structure to a denser soil structure. Thus, geopolymer-based palm oil boiler ash and laterite soil may be a potential by-product as an alternative to soil treatment in geotechnical applications that minimize porosity and potentially reduce permeability.

\section{ACKNOWLEDGEMENT}

The author would like to acknowledge the help of Associate Professor Dr. Ts. Mazidah Mukri as a post-graduate supervisor in this study. This work is also supported by the Faculty of Civil Engineering and Faculty of Chemical Engineering, UiTM Johor Campus, Pasir Gudang for their facilities in the testing laboratory.

\section{REFERENCES}

[1] Hai TC, Ng A, Prudente C, Pang C, Tek Choon Yess, J. (2001) Balancing the Need for Sustainable Oil Palm Development and Conservation: The Lower Kinabatangan Floodplains Experience. Strategic Directions for The Sustainability of the Oil Palm Industry, 53 pp. Retrieved From http://Assets.Panda.Org/Downloads/Balancingtheneed.pdf

[2] Abdullah N, Sulaim F. (2013) The Oil Palm Wastes in Malaysia. in Biomass Now Sustainable Growth and Use. Intech. https://doi.Org/10.5772/55302

[3] Mangi,SA, Ibrahim MHW, Jamaluddin N, Arshad MF, Memon, FA, Jaya RP, Shahidan S. (2018) A Review on Potential Use of Coal Bottom Ash as a Supplementary Cementing Material in Sustainable Concrete Construction. International Journal of Integrated Engineering, 10(9): 127-135. https://doi.Org/10.30880/Ijie.2018.10.09.006

[4] Deraman LM, Al Bakri Abdullah,MM, Ming LY, Hussin K, Yahya Z. (2015) A Review on Processing and Properties of Bottom Ash Based Geopolymer Materials. in Key Engineering Materials, 660: 3-8. https://doi.Org/10.4028/www.Scientific.Net/KEM.660.3

[5] Davidovits J. (2005) Geopolymer, Green Chemistry and Sustainable Development Solutions. in J. Davidovits (Ed.), Proceedings of the World Congress Geopolymer 2005 (p. 236). Institut Geopolymere.

[6] Wattimena OK, Antoni, Hardjito D. (2017) A review on the effect of fly ash characteristics and their variations on the synthesis of fly ash based geopolymer. in AIP Conference Proceedings, 1887: 020041. https://doi.org/10.1063/1.5003524

[7] H Xu, Van Deventer JSJ. (2000) The geopolymerisation of alumina-silicate minerals. Int. J. Miner. Process., 59(3): 247-266. 
[8] Van Jaarsveld JGS, Van Deventer JSJ, Lorenzen L. (1997) Potential use of geopolymeric materials to immobilize toxic metals: Part I. Theory and applications, Miner. Eng., 10(7): 659-669.

[9] Kanesan D, Ridha S, Rao P. (2017) Formulation of geopolymer cement using mixture of slag and class $\mathrm{f}$ fly ash for oil well cementing. In IOP Conference Series: Materials Science and Engineering, 201: 012014. https://doi.org/10.1088/1757-899x/201/1/012014

[10] Nanavati S, Chetan Nanavati S, Jaywant Lulla S, Ranjeet Singh A, Bharat Mehta D, Mohan Patel A, Author C. (2017) A review on fly ash based geopolymer concrete. IOSR Journal of Mechanical and Civil Engineering, 14(4): 12-16. https://doi.org/10.9790/1684-1404071216

[11] Kabir SMA, Alengaram UJ, Jumaat MZ, Sharmin A, Islam A. (2015) Influence of molarity and chemical composition on the development of compressive strength in POFA based geopolymer mortar. Advances in Materials Science and Engineering, 2015: 647071 https://doi.org/10.1155/2015/647071.

[12] Yahya Z, Abdullah MMAB, Hussin K, Ismail KN, Razak RA, Sandu AV. (2015) Effect of solids-to-liquids, $\mathrm{Na}_{2} \mathrm{SiO}_{3}$-to- $\mathrm{NaOH}$ and curing temperature on the palm oil boiler ash $(\mathrm{Si}+$ Ca) geopolymerisation system. Materials, 8(5): 2227-2242. https://doi.org/10.3390/ma8052227.

[13] Lopez E., Vega-Zamanillo A., Calzada Perez M.A., \& Hernandez-Sanz A. (2015). Bearing capacity of bottom ash and its mixture with soils. Soils and Foundations, 55, 529-535. https://doi.org/10.1016/j.sandf.2015.04.005

[14] Jindal B. B. (2019). Investigations on the properties of geopolymer mortar and concrete with mineral admixtures: A review. Construction and Building Materials. Elsevier Ltd. https://doi.org/10.1016/j.conbuildmat.2019.08.025.

[15] Ma C. K, Awan, A. Z., \& Omar W. (2018). Structural and material performance of geopolymer concrete: A review. Construction and Building Materials. Elsevier Ltd. https://doi.org/10.1016/j.conbuildmat.2018.07.111.

[16] Duchesne J., Duong L., Bostrom T., \& Frost R. (2010). Microstructure study of early in situ reaction of fly ash geopolymer observed by environmental scanning electron microscopy (ESEM). Waste and Biomass Valorization, 1(3), 367-377. https://doi.org/10.1007/s1264910-9036-4.

[17] Khan, H., Purohit, D., Bagara, D., \& Pahadiya, H.S. (2016). Geopolymer Concrete with Replacement of Cement. International Journal of Engineering Research \& Technology (IJERT) 4-23.

[18] Emdadi, Z., Asim, N., Amin, M. H., Yarmo, M. A., Maleki, A., Azizi, M., \& Sopian, K. (2017). Development of Green Geopolymer Using Agricultural and Industrial waste Materials with High Water Absorbency. Applied Sciences (Switzerland), 7(5). https://doi.org/10.3390/app7050514.

[19] Puertas, F. \& Martinez-Ramiirez, S \& Alonso, S \& Vazquez, T. (2000). Alkali-Activated Fly Ash/Slag Cement Strength Behavior and Hydration Products. Cement and Concrete Research. 301. 1625-1632.

[20] Skvara, F., Kopecky, L., Nemecek, J., \& Bittnar, Z. (2006). Microstructure of geopolymer materials based on fly ash. Ceramics - Silikaty, 50(4), 208-215.

[21] Rosli, Ros, Nadiah. (2017). Properties of Laterite Soils from Sources Near Nibong Tebal, Malaysia. Conference: ICONTES Vistana Hotel Kuala Lumpur https://www.researchgate.net/publication/324720622

[22] Sujeeth, Ahmed. (2015). An Investigation into The Geotechnical Engineering Properties of Laterite Soils in Nilai, Malaysia. 10.13140/RG.2.2.20036.04489.

[23] Marto, A., Latifi, N., \& Sohaei, H. (2013). Stabilization of laterite soil using GKS soil stabilizer. Electronic Journal of Geotechnical Engineering, 18 C, 521-532.

[24] Parikshith, M. V., \& Sekhar, D. C. (2019). Feasibility of fly-ash based geopolymer for soil stabilization. International Journal of Innovative Technology and Exploring Engineering, 9(1), 4348-4351. https://doi.org/10.35940/ijitee.A5019.119119

[25] Mukri, M., Aziz, N. N. S., \& Khalid, N. (2018). Geopolymer Effect in Modelling Hydraulic Conductivity for Designing Soil Liner of Laterite Soil. International Journal of Civil Engineering and Technology, 9(7), 1962-1974. 
[26] Liu, Z., Cai, C. S., Liu, F., \& Fan, F. (2016). Feasibility study of loess stabilization with fly ash-based geopolymer. Journal of Materials in Civil Engineering, 28(5). https://doi.org/10.1061/(ASCE)MT.1943-5533.0001490.

[27] Nikolic, I., Zejak, R., Radmilovic, V., Blecic, D., \& Tadic, M. (2012). Geopolymerization of fly ash as a possible solution for stabilization of used sandblasting grit.

[28] Thiha, S., Lertsuriyakul, C., \& Phueakphum, D. (2018). Shear Strength Enhancement of Compacted Soils Using High-Calcium Fly Ash-Based Geopolymer. International Journal of GEOMATE, 15(48), 1-9. https://doi.org/10.21660/2018.48.35692

[29] Dheyab, W., Ismael, Z. T., Hussein, M. A., \& Huat, B. B. K. (2019). Soil stabilization with geopolymers for low cost and environmentally friendly construction. International Journal of GEOMATE, 17(63), 271-280. https://doi.org/10.21660/2019.63.8159

[30] Nik Ab Aziz, N. N. S., Mukri, M., Hashim, S., \& Khalid, N. (2015). Influence of Compaction Effort for Laterite Soil Mix with Geopolymer In Designing Soil Liner. Electronic Journal of Geotechnical Engineering, 20(22), 12353-12364.

[31] Ahmad, F. H., Mukri, M., \& Azmi, N. A. C. (2017). Effectiveness of Different Percentage of Bentonite in Soil Liner on Interface Shear Strength with Geosynthetic. International Journal of Applied Engineering Research, 12(7), 1360-1364.

[32] Ashraf, M. A., Hossen, M. A., Ali, M. A., \& Chakaraborty, B. P. (2018). Stabilization of Soil by Mixing with Different Percentages of Lime, 1-10. The 4th International Conference on Civil Engineering for Sustainable Development

[33] Zhou, S. Q., Zhou, D. W., Zhang, Y. F., \& Wang, W. J. (2019). Study on PhysicalMechanical Properties and Microstructure of Expansive Soil Stabilized with Fly Ash and Lime. Advances in Civil Engineering. https://doi.org/10.1155/2019/4693757

[34] Fattah, M., Y., Al-Saidi, A., And Jaber, M. (2014) Consolidation Properties of Compacted Soft Soil Stabilized with Lime-Silica Fume Mix. International Journal of Scientific \& Engineering Research, 5, 1675-1682.

[35] Noushini, A., \& Castel, A. (2016). The Effect of Heat-Curing on Transport Properties of Low-Calcium Fly Ash-Based Geopolymer Concrete. Construction and Building Materials, 112, 464-477. https://doi.org/10.1016/j.conbuildmat.2016.02.210.

[36] Nawaz, M. F., Bourrié, G., \& Trolard, F. (2013). Soil Compaction Impact and Modelling. A Review. Agronomy for Sustainable Development, 33(2), 291-309. https://doi.org/10.1007/s13593-011-0071-8.

[37] Khale, D., \& Chaudhary, R. (2007). Mechanism of Geopolymerization and Factors Influencing Its Development: A Review. Journal of Materials Science, 42(3), 729-746. https://doi.org/10.1007/s10853-006-0401-4.

[38] Alvarez-Ayuso, E., Querol, X., Plana, F., Alastuey, A., Moreno, N., Izquierdo, M., Barra, M. (2008). Environmental, Physical and Structural Characterization of Geopolymer Matrixes Synthesized from Coal (Co-)Combustion Fly Ashes. Journal of Hazardous Materials, 154(13), 175-183. https://doi.org/10.1016/j.jhazmat.2007.10.008

[39] Temuujin, J., \& Van Riessen, A. (2009). Effect of Fly Ash Preliminary Calcination on The Properties of Geopolymer. Journal of Hazardous Materials, 164(2-3), 634-639. https://doi.org/10.1016/j.jhazmat.2008.08.065. 